\title{
Primary gastric rupture in 20 horses from Midwestern Brazil: case report
}

\author{
[Ruptura gástrica primária em 20 equinos no Centro-Oeste do Brasil: relato de caso] \\ M.C. Gonzaga ${ }^{1}$, T.M. Wilson ${ }^{1}$, M.B. Castro $^{2}$, A.R. Teixeira-Neto ${ }^{2}$, \\ R.C. Campebell ${ }^{2}$, A.C.L. Câmara ${ }^{3}$ \\ ${ }^{1}$ Aluno de pós-graduação - FAV - Universidade de Brasília - Brasília, DF \\ ${ }^{2}$ Faculdade de Agronomia e Medicina Veterinária - FAV - Universidade de Brasília - Brasília, DF \\ ${ }^{3}$ Médico veterinário - FAV - Universidade de Brasília - Brasília, DF
}

\begin{abstract}
An 11-year (2007-2018) survey of epidemiological, clinical and pathological findings of horses with primary gastric rupture (PGR) was conducted. Twenty horses presented PGR, nine (45\%) horses were clinically evaluated, eleven (55\%) were sent dead, and all animals were necropsied. PGR contributed to a prevalence of $0.31 \%(9 / 2,868)$ of all equid attendances, $1.83 \%(9 / 491)$ of colic cases, and $4.1 \%(20 / 487)$ of all equid necropsies. Highly fermentable feed $(n=7)$, gastric impaction $(n=4)$, and perforating gastric ulcer $(n=1)$ were the main causes of PGR; whilst eight horses presented idiopathic gastric rupture. Clinically evaluated horses were tachycardic, tachypneic, febrile, dehydrated, with increased abdominal tension, abnormal mucous membranes and reduced to absent intestinal borborygmi. Improper dietary management, such as the ingestion of low-quality roughage and highly fermentable feedstuffs were detected as the main factors associated with PGR in Midwestern Brazil. It is important to raise awareness in horse owners about proper feed management to minimize PGR.
\end{abstract}

Keywords: acute abdomen, gastropathy, stomach, peritonitis

\section{RESUMO}

Foi realizado um levantamento de 11 anos (2007-2018) dos achados epidemiológicos, clínicos e patológicos de equinos com ruptura gástrica primária (RGP). Vinte equinos apresentaram RGP, dos quais nove (45\%) foram avaliados clinicamente e 11 (55\%) foram enviados mortos, sendo todos os animais necropsiados. A RGP contribuiu com prevalência de 0,31\% de todos os atendimentos de equídeos (9/2.868), 1,83\% (9/491) dos casos de cólica, e 4,1\% (20/487) das necropsias em equídeos. Alimentos altamente fermentáveis $(n=7)$, compactação gástrica $(n=4)$ e perfuração de úlcera gástrica $(n=1)$ foram as principais causas de RGP, enquanto oito equinos tiveram ruptura gástrica idiopática. Os equinos avaliados clinicamente apresentaram-se taquicárdicos, taquipneicos, febris, desidratados, com mucosas anormais, aumento da tensão abdominal e motilidade intestinal reduzida. $O$ manejo inadequado da dieta, como a ingestão de forragens de baixa qualidade e alimentos altamente fermentáveis, foi o principal fator de risco associado à RGP no Centro-Oeste do Brasil. É importante aumentar a conscientização dos proprietários de equinos sobre o manejo alimentar adequado para minimizar a $R G P$.

Palavras-chave: abdômen agudo, estômago, gastropatia, peritonite

\section{INTRODUCTION}

Gastric ruptures are an almost invariably fatal complication of equine colic, and mostly result from over distension of the stomach by ingesta, fluid or gas, and also due to perforating gastric ulcers (Dechant and Winfield, 2017). Primary gastric rupture (PGR) occurs directly from gastric injuries or over distension, and secondary gastric ruptures are associated with physical or functional intestinal obstructions. Idiopathic gastric rupture might be considered a subcategory of PGR with an unknown etiology (Todhunter et al., 1986; Kiper et al., 1990;

Recebido em 29 de maio de 2019

Aceito em 23 de outubro de 2019

*Autor para correspondência (corresponding author)

E-mail: aclcamara@yahoo.com.br 
Winfield and Dechant, 2015; Dechant and Winfield, 2017).

Surveys of PGR in horses are rarely reported (Winfield and Dechant, 2015), and have never been performed in Brazil. Therefore, the present study aimed to report epidemiological, clinical and pathological findings of 20 cases of PGR in horses from Midwestern Brazil.

A survey in the records of equids attended in the past eleven years (2007-2018) at the Large Animal Veterinary Teaching Hospital, Universidade de Brasília, located in Midwestern Brazil, was conducted. The total number of equid attendances, acute abdomen and gastropathies (gastric ulcer syndrome - GUS, gastric dilation, gastric impaction, and gastric rupture) cases, and necropsies on equids during this period were recorded.

All gastric ruptures were diagnosed by surgical exploration (midline celiotomy) or at necropsy. Epidemiological data (breed, gender, age, feed, and clinical evolution), and initial clinical suspicion (which is solely based on owner's or practitioner's information prior to physical evaluation) of all horses were retrieved. Additionally, nine horses were clinically evaluated and some parameters (heart and respiratory rates, mucous membrane color, rectal temperature, capillary refill time, intestinal motility, abdominal distension, gastric reflux appearance, manure characteristics, and rectal palpation findings) were determined. Location and characteristics of the rupture in the stomach were also recorded in horses at necropsy and the etiology of the PGR was determined as known or idiopathic cause (Winfield and Dechant, 2015).

During the 11-year period of this study, a total of 2,868 equids were admitted, and 487 equids were necropsied. Acute abdomen cases represented $17.1 \%(491 / 2,868)$ of all cases. Gastropathies were detected in 122 horses $(24.8 \%$ - 122/491), and included gastric dilation $(55.7 \%-68 / 122)$, GUS (10.7\% - 13/122), gastric impaction $(17.2 \%$ - 21/122), and gastric rupture (16.4\% - 20/122). All gastric ruptures were classified as PGR. Nine $(45 \%-9 / 20)$ horses were clinically evaluated, eleven $(55 \%-11 / 20)$ dead horses went directly to pathology service; but all animals were necropsied. Thus, PGR achieved a prevalence of $0.31 \%(9 / 2,868)$ of all attendances, $1.83 \%$
(9/491) of the colicky equids, and 4.1\% (20/487) of all equid necropsies.

Epidemiological data on twenty horses with PGR is summarized on Table 1. Thirteen male and seven females were affected. PGR cases included five Quarter horses, five mixed breed, four Mangalarga Marchador, two Campolina, one Thoroughbred, one Crioulo, one Westphalia, and one Arabian horse. Most cases (65\% - 13/20) occurred during the dry season (April to September) in Midwestern Brazil. Feed data were available in thirteen $(65 \%)$ cases, and included Tifton hay (Cynodon dactylon), corn straw, fresh grass, alfalfa hay, silage and pelleted or grounded ration (2-6 kg daily). Unusual feeding material, such as restaurant waste (human feed leftovers), was present in the diet of two mares from the same farm (Case 10 and 11).

Main clinical findings from nine horses with PGR are shown in Table 2. All horses had a clinical evolution ranging from 12 to $48 \mathrm{~h}$ $(22 \pm 4.9$ h). Eight animals $(88.8 \%)$ presented tachycardia (60-140 beats per minute); tachypnea (30-56 breaths per minute) and increased capillary refill time (equal to/greater than 3 seconds). A single mare (Case 5) had been repeatedly medicated (approximately $40 \mathrm{~mL}$ of flunixin meglumine and parenteral fluids in previous $12 \mathrm{~h}$ ) by its owner and presented physiologic clinical parameters. Abnormal mucous membranes (congested, hyperemic, cyanotic, and presence of toxemic halo) were detected in seven $(77.7 \%)$ horses. Rectal temperature data were available in six cases; three horses were febrile $(3 / 6-50 \%)$, and two hypothermic $(2 / 6-33.3 \%)$. Intestinal motility was decreased (hypomotility) or absent (amotile) in four horses each. Gastric reflux was recorded in eight horses $(88.8 \%)$, and varied from brownish (3/8), bloody (2/8), yellowish (1/8) coloration or abundant saliva with mucus (1/8), and gas-fermented odor (1/8). Abdominal distension was associated to bilateral tympany in five $(55.5 \%)$ cases. Feces varied from dry/small with mucus (1/6) to pasty (2/6) or liquid (1/6); two horses had no feces $(2 / 6)$ and one presented tenesmus as well. Rectal palpation findings in six horses included no abnormalities (2/6) or gasdistended bowel (4/6). Three horses $(33.3 \%$ 3/9) were submitted to exploratory celiotomy, and six $(66.7 \%$ - 6/9) horses died within few hours or were humanely euthanized. 
Eight dead horses $(72.7 \%$ - 8/11) presented acute abdomen signs previous to death, and three $(27.3 \%$ - 3/11) were found dead. PGR were categorized as idiopathic $(n=8)$ or having a known cause $(n=12)$. Gastric ruptures were associated with highly fermentable feed in seven horses (Case 4, 5, 9, 10, 11, 14, 16), gastric impaction in four horses (Case 1, 13, 19, 20), and perforating gastric ulcer in one horse (Case 2). Abdominal tympany, accumulation of liquids and gastric contents on the peritoneal cavity (Figure 1), associated with fibrin clots adhered to the organs' serous surfaces or free in the cavity were the main necropsy findings in horses with PGR. All gastric ruptures occurred in the greater curvature of the stomach, and presented linear (Figure 1), circular (Figure 2) or wedge-shaped seromuscular and mucosal tears, measuring 3 to $30 \mathrm{~cm}$, surrounded by hemorrhage margins and transmural necrosis (Figure 3). Edema, petechiae, ecchymoses and suffusions were also observed in the serosa of the intestinal loops, mesentery and peritoneum surrounding the gastric ruptures. Diaphragmatic rupture (Case 10), uterine laceration (Case 17) and approximately 50L of inodorous watery fluid filling the abdominal cavity of a mare with gastric rupture (Case 1) as a result of an improper gastric lavage with a nasogastric tube were also observed.

Table 1. Epidemiological data from 20 horses with primary gastric rupture from Midwestern Brazil

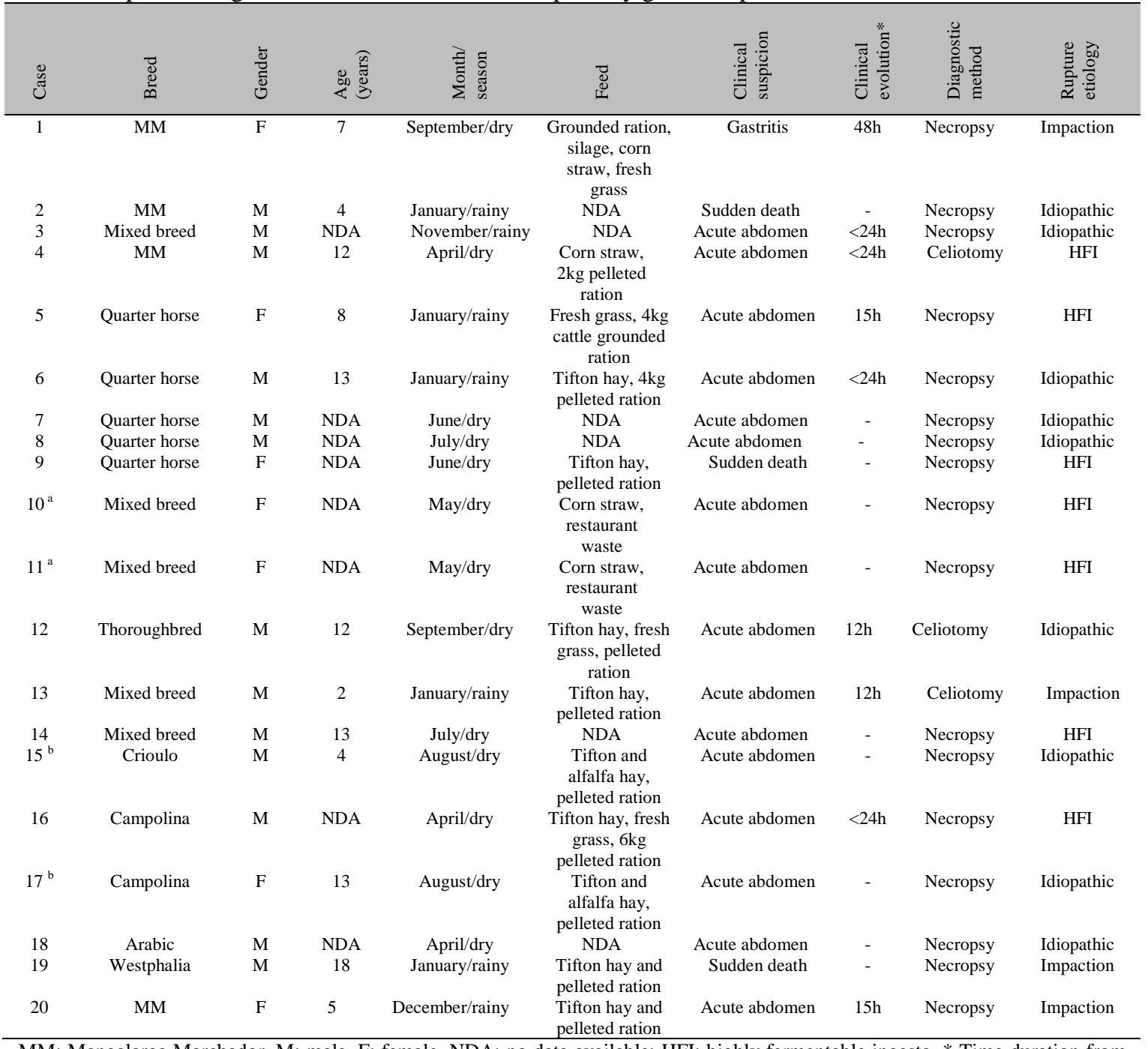

MM: Mangalarga Marchador, M: male, F: female, NDA: no data available; HFI: highly fermentable ingesta. * Time duration from first symptoms observed by the owner or handler, until death or euthanasia. Horses with no clinical evolution data died and were delivered to pathology service. ${ }^{\mathrm{a}, \mathrm{b}}$ Identical letters represent horses from the same farm. 
Table 2. Clinical findings from nine horses with primary gastric rupture from Midwestern Brazil

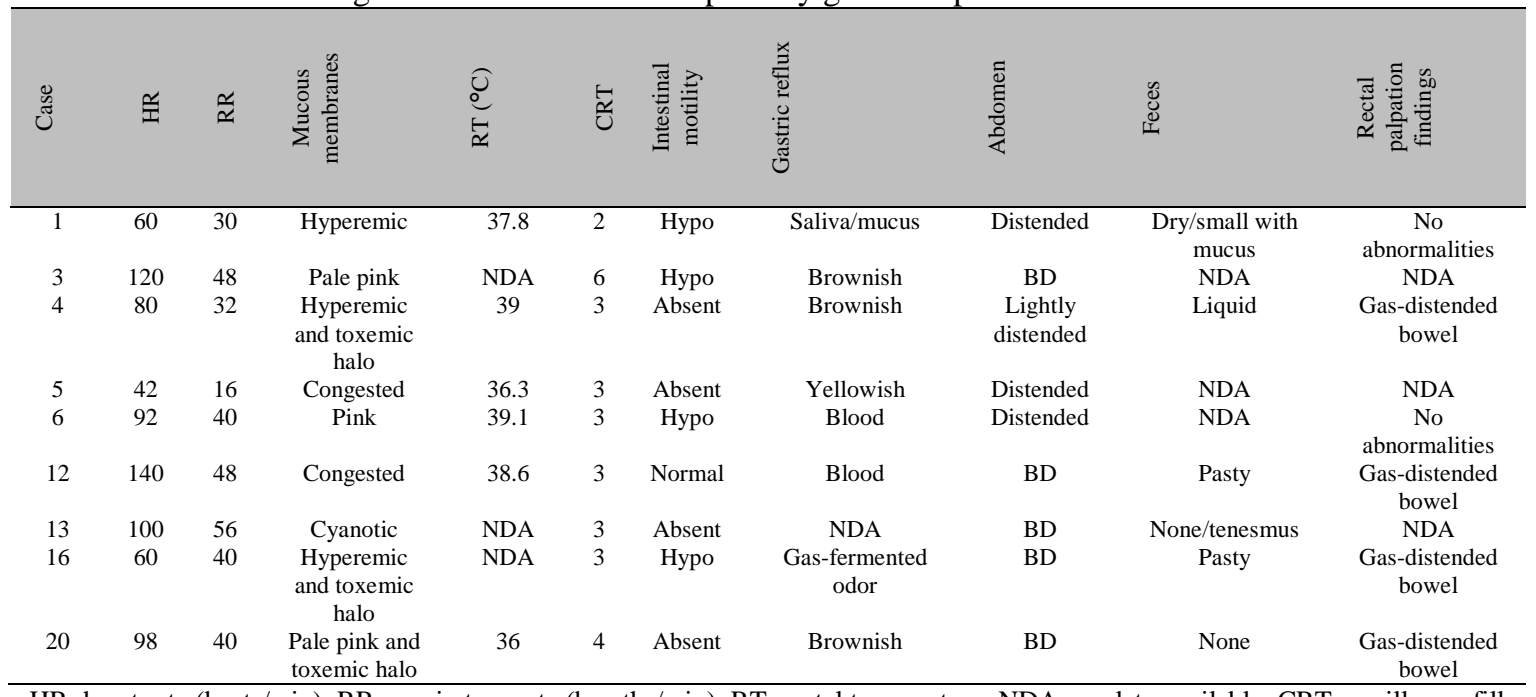

HR: heart rate (beats/min); RR: respiratory rate (breaths/min); RT: rectal temperature; NDA: no data available; CRT: capillary refill time (seconds); BD: bilateral distension.

\section{DISCUSSION AND CONCLUSION}

Historically, primary and secondary gastric ruptures presented $5-8 \%$ prevalence of colic presentations (Todhunter et al., 1986; Kiper et al., 1990). Recently, one study found a much lower prevalence $(0.5 \%)$ evaluating PGR cases only (Winfield and Dechant, 2015). Our data shows more than a three-fold prevalence of PGR $(1.83 \%)$ in horses from Midwestern Brazil. The high frequency of gastropathies $(24.8 \%)$ in our study could justify the higher number of PGR cases. However, it is important to emphasize that acute and untreated gastropathies may rapidly evolve to gastric ruptures and death (Todhunter et al., 1986; Vainio et al., 2011).

PGR was associated to gastric impaction in four horses, including a gastric rupture secondary to nasogastric intubation and gastric lavage in one mare (Case 1). Gastric impaction might be difficult to manage clinically since recovering poorly digested or grain feed via nasogastric tube may be challenging (Vainio et al., 2011). Additionally, a recent study on Brazilian mixed breed horses points to the need to proceed carefully during enteral fluid replacement in order to prevent gastric dilation and possible rupture in mares (Di Filippo et al., 2016).
Idiopathic gastric ruptures observed in eight horses $(40 \%-8 / 20)$ represents a challenge for diagnosis and preventive management, confirming that gastric rupture etiology may not be evident on necropsy (Todhunter et al., 1986; Kiper et al., 1990; Winfield and Dechant, 2015). Traumatic etiology was suspected and not confirmed in two mares with idiopathic PGR and uterine (Case 17) or diaphragmatic (Case 10) lacerations. It is known that the stomach location in the cranial abdomen, protected by the rib cage, make this organ less prone to traumatic injuries (Dechant and Winfield, 2017). Nevertheless, dramatic response of horses to acute abdominal pain might lead the animal to throw itself on the ground allowing a maximally distended stomach to rupture.

In general, PGR horses analyzed in this study presented relevant signs of systemic inflammatory response syndrome (tachycardia, tachypnea, fever, and abnormal mucous membranes), and mean clinical evolution in hospital-admitted horses was 22-hours. Additionally, 8 of 11 (72.7\%) dead horses showed acute abdomen signs previous to death. These findings reinforce that many owners still neglect seeking prompt and adequate veterinary assistance, thinking that referring horses to hospital services is too expensive (Oliveira et al., 2014). 


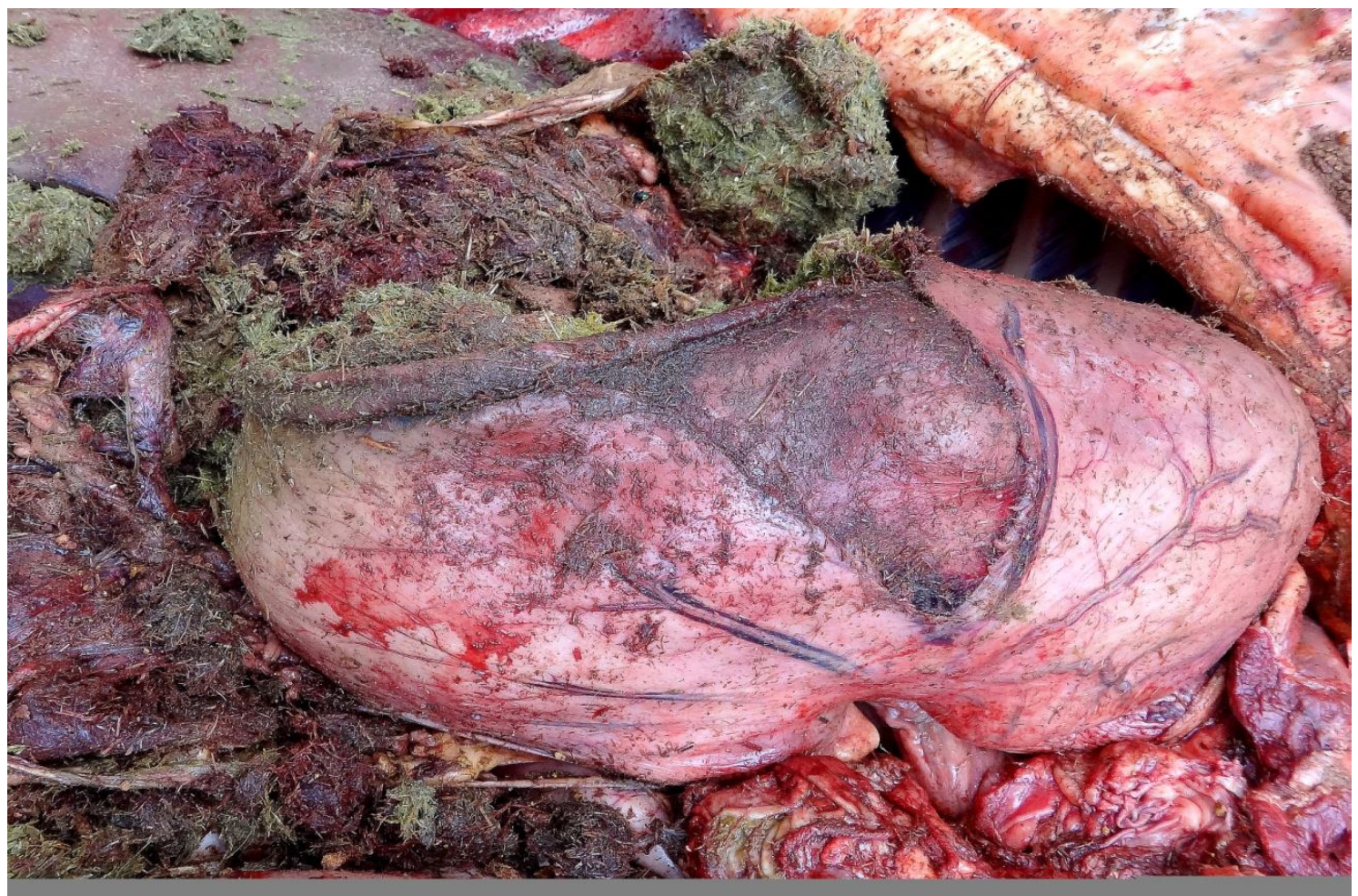

Figure 1. Horse (Case 19), stomach. Gastric rupture with mucosal tears, distinction of the seromuscular layers and food contents on the peritoneal cavity and abdominal organs.

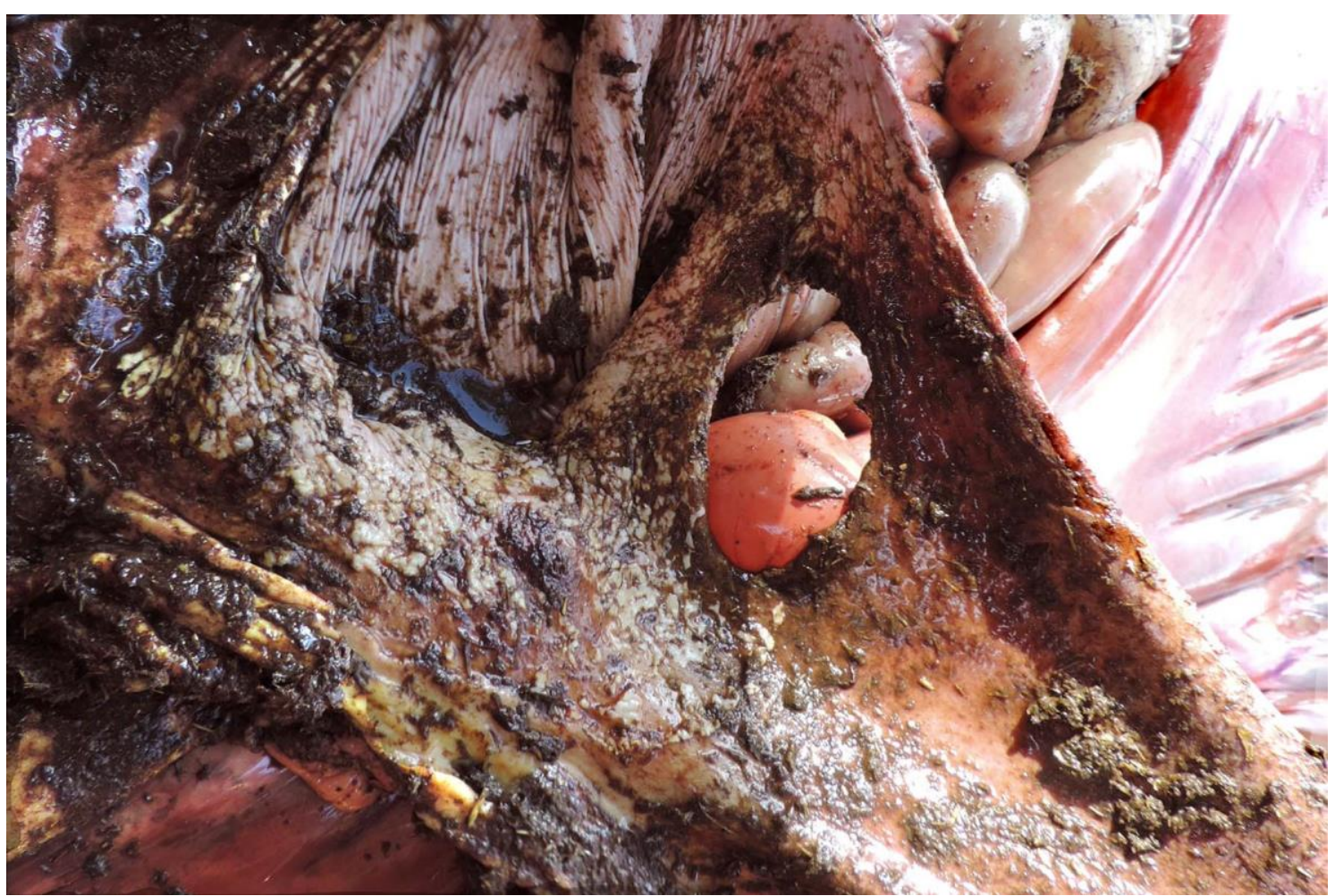

Figure 2. Horse (Case 2), stomach, greater curvature. Transmural circular rupture associated with perforating gastric ulcer. 


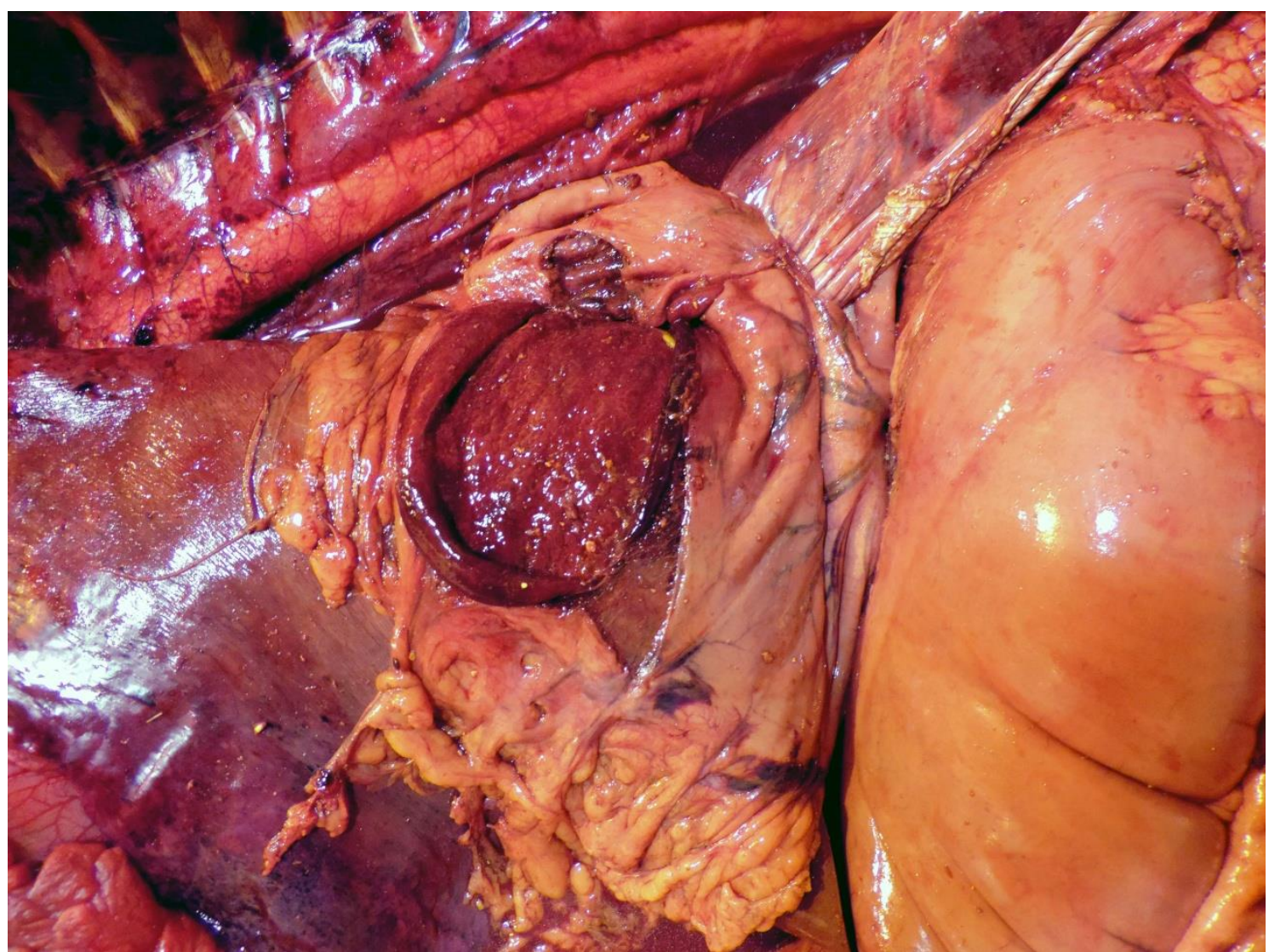

Figure 3. Horse (Case 14), stomach. Gastric perforation surrounded by necrohemorrhagic margins.

Pathological findings herein confirmed that the great curvature of the stomach is the most common anatomical site vulnerable to ruptures, as previously reported in horses (Todhunter et al., 1986; Kiper et al., 1990; Winfield and Dechant, 2015; Di Filippo et al., 2016). Gastric distention leads to over stretching of the stomach tissues causing mucosal and seromuscular layers to weaken and tear with hemorrhagic borders (Kiper et al., 1990; Brown et al., 2007). Distractive forces on the stomach wall resulting from gastric distention lead to rupture of the seromuscular layer followed by rupture of the mucosa (Winfield and Dechant, 2015; Di Filippo et al., 2016).

PGR continues to be an unpredictable and frustrating diagnosis (Winfield and Dechant, 2015). In Midwestern Brazil, proper nutritional management, and prompt and adequate veterinary assistance are essential measures to prevent and minimize the occurrence of acute abdomen, avoiding gastric rupture and reducing mortality from this disease.

\section{REFERENCES}

BROWN, C.C.; BAKER, D.C.; BARKER, I.K. Stomach and abomasum. In: JUBB, K.V.F.; KENNEDY, P.C.; PALMER, N. (Eds.). Jubb, Kennedy, and Palmer's Pathology of domestic animals. 5.ed. New York: Elsevier Saunders, 2007. p.52-68.

DECHANT, J.E.; WINFIELD, L.S. Review of gastric rupture in the horse. Equine Vet. Educ., v.29, p.677-682, 2017.

DI FILIPPO, P.A.; COUTINHO, I.S.; MEIRELES, M.A.D. et al. Resistance to rupture of the equine stomach. Pesqui. Vet. Bras., v.36, p.1087-1090, 2016. 
KIPER, M.L.; TRAUB-DARGATZ, J.; CURTIS, C.R. Gastric rupture in horses: 50 cases. J. Am. Vet. Med. Assoc., v.196, p.333-336, 1990.

OLIVEIRA, C.M.M.; RIBEIRO, I.B.; GADELHA, I.C.N. et al. Colic in equidae from Rio Grande do Norte: retrospective study of the main clinical and epidemiological findings in 25 cases. Acta Vet. Bras., v.8, p.290-294, 2014.
TODHUNTER, R.J.; ERB, H.N.; ROTH, L. Gastric rupture in horses: a review of 54 cases. Equine Vet. J., v.18, p.288-293, 1986.

VAINIO, K.; SYKES, B.W.; BLIKSLAGER, A.T. Primary gastric impaction in horses: a retrospective study of 20 cases (2005-2008). Equine Vet. Edu., v.23, p.186-190, 2011.

WINFIELD, L.S.; DECHANT, J.E. Primary gastric rupture in 47 horses (1995-2011). Can. Vet. J., v.56, p.953-958, 2015. 